\title{
TRIBUTACIÓN DE LAS GANANCIAS QUE SE OBTIENEN DEL ILÍCITO PENAL
}

\author{
Ricardo DE Mosteyrín SAMPALO \\ Fiscal de Delitos Económicos \\ de la Fiscalía Provincial de Las Palmas \\ Doctor en Derecho \\ rmossam@justiciaencanarias.org
}

\begin{abstract}
RESUMEN
Se aborda la problemática de la tributación de las ganancias ilícitas en general y de las delictivas en particular, con una breve referencia al Derecho comparado y analizando a fondo la doctrina y la jurisprudencia españolas sobre la materia. Se defiende la postura favorable a la tributación como única admisible en nuestro ordenamiento jurídico. Palabras clave: Derecho penal, tributación, ganancias ilícitas, ganancias delictivas, Nécora, Roldán, Urralburu, fraude fiscal.
\end{abstract}

\section{ABSTRACT}

Here we are dealing with the issue of illegal income taxation in general and of criminal income in particular, briefly referring to comparative law with a detailed analysis of Spanish doctrine and the case law on the subject. The fact of being in favour is regarded as the only position viable in our legal system.

Keywords: Penal Law, taxation, illegal income, criminal income, Necora, Roldan, Urralburu, tax fraud.

\section{ZUSSAMENFASSUNG}

Es wird die Besteuerung von strafrechtlichen Einkünften im allgemeinen behandelt und im konkreten Straffall. Hierzu erfolgt ein kurzer Bezug zum Vergleichenden Recht und es wird der Hintergrund sowie die spanische Rechtsprechung zum Thema analysiert. Es wird der Standpunkt der Befürwortung als der einzig zulässige in unserer Rechtsordnung vertreten.

Schlüsselwörter: Strafrecht, Besteuerung, unzulässige Einnahmen, Strafrechtliche Einkünfte, Nécora, Roldán, Urralburu, Steuerhinterziehung.

SUMARIO. I. PLANTEAMIENTO.-II. DERECHO COMPARADO.-1. Estados Unidos.-2. Europa.-III. JURISPRUDENCIA.-1. Caso Nécora.-2. Caso Roldán.-3. Caso Urralburu.-4. Sentencias posteriores.-IV. DOCTRINA.-1. Teoría de la no tributación de las ganancias ilícitas.-2. Teoría favorable a la tributación de las ganancias ilícitas.-3. Teoría intermedia de Herrera Molina.-4. Teoría intermedia de Galarza.--V. CONCLUSIONES. 


\section{PLANTEAMIENTO}

A mayor riesgo, mayor rentabilidad. Una exposición sobre la tributación de las ganancias ilícitas debe partir de este postulado, pues es éste el motivo por el que los negocios más rentables son los negocios ilícitos. El temor a sufrir sanciones incluso privativas de libertad, además del decomiso de lo invertido y de lo ganado, disuade a los competidores, y toda la ganancia se la reparten los pocos, o no tan pocos, que se arriesgan a realizar estas actividades.

Siempre ha habido algunas actividades ilícitas especialmente lucrativas; históricamente, aunque no siempre ilícitas, la piratería, la usura o el tráfico negrero han sido algunas de ellas. Modernamente son muy lucrativos el tráfico de drogas, el de armas, el de personas, así como otros delitos como la corrupción política y administrativa.

Partiendo de esta base se aprecia la importancia del estudio del tratamiento jurídico que deben recibir esas ganancias. Por un lado puede entenderse que quedan sujetas a tributación como si de cualquier otra ganancia se tratase, y que en caso de no tributación se incurrirá, de superarse el umbral delictivo de 120.000 euros en un mismo periodo impositivo a que se refiere el art. $305 \mathrm{CP}$, en delito de fraude fiscal. Por otro lado se ha sostenido por parte de la doctrina, por diversos argumentos que luego se expondrán, que estas ganancias no están sujetas a tributación.

Anticipo ya que la posición que aquí se mantendrá será favorable a la tributación de las ganancias ilícitas y a que es posible condenar por delito de fraude fiscal en caso de que no se tribute por ellas, siempre que se rebase el umbral delictivo. Aunque los argumentos en que se basa nuestra posición se desarrollarán más adelante, destacamos aquí la gran amplitud con que se configura el hecho imponible en la LIRPF. Así, su art. 2 establece que «constituye el objeto de este impuesto la renta del contribuyente, entendida como la totalidad de sus rendimientos, ganancias y pérdidas patrimoniales y las imputaciones de renta que se establezcan por la ley, con independencia del lugar donde se hubiesen producido y cualquiera que sea la residencia del pagador». El art. 6 LIRPF concreta las fuentes de ingresos, y una de ellas es «ganancias y pérdidas patrimoniales», concepto que se desarrolla en los arts. 33 y siguientes de la LIRPF, estableciendo el art. 39.1 que «tendrán la consideración de ganancias de patrimonio no justificadas los bienes o derechos cuya tenencia, declaración o adquisición no se corresponda con la renta o patrimonio declarados por el contribuyen- 
te, así como la inclusión de deudas inexistentes en cualquier declaración por este impuesto o por el Impuesto sobre el Patrimonio, o su registro en los libros o registros oficiales. Las ganancias patrimoniales no justificadas se integrarán en la base liquidable general del periodo impositivo respecto del que se descubran, salvo que el contribuyente pruebe suficientemente que ha sido titular de los bienes o derechos correspondientes desde una fecha anterior a la del periodo de prescripción».

Lo hasta aquí dicho pone de relieve la lógica pretensión omnicomprensiva del legislador en lo que a tributación se refiere, quedando exentas de tributación tan sólo ciertas rentas que menciona expresamente el art. 7 LIRPF. Por tanto, lo que el art. 39 LIRPF pretende establecer es una suerte de cláusula de cierre para no dejar ninguna fuente posible de renta sin mencionar. Esta cláusula de cierre, al referirse a bienes o derechos que no se corresponden con lo declarado por el contribuyente, no entiendo que haya razón para considerarla restringida únicamente a lo ganado lícitamente y no declarado, pues no dice tal el tenor de la norma, sino que se refiere a todo lo ganado y no declarado, incluyendo, por tanto, lo que se haya ganado ilícitamente, e incluso aunque se haya ganado mediante ilícitos penales.

Es muy probable que en realidad el legislador español no se haya planteado esta posibilidad, pero queriendo sujetar todo tipo de ganancias a la tributación, se ha configurado el IRPF de manera que contenga también la ganancia ilícita, ya que, en definitiva, se comprende toda la ganancia salvo la expresamente excluida, y la ilícita no es una de ellas. No obstante, sería acertado que se mencionara expresamente esta fuente de ganancia como sujeta a tributación para despejar cualquier duda que se pueda suscitar al respecto.

\section{DERECHO COMPARADO}

\section{Estados Unidos}

En Estados Unidos se resolvió muy pronto esta cuestión, pues ya desde la Ley Seca ${ }^{1}$, con intención de que se tributara también por las ganancias ilícitas, se comenzó a considerar renta a efectos fiscales cualquier ganancia, con independencia de la fuente de la que proviniera. Así, en 1916 se introdujo una reforma legislativa en el Income Tax Act que suprimió el término

\footnotetext{
${ }^{1}$ La Ley Seca estuvo vigente desde enero de 1920 hasta diciembre de 1933.
} 
«legal» referido al origen de la deuda y se utilizó la expresión «todo ingreso procedente de cualquier fuente de ingreso» ${ }^{2}$.

No obstante, en la práctica jurisprudencial, aunque esta teoría acabó imponiéndose con rotundidad, hubo ciertas vacilaciones que destaca Herrea Molina ${ }^{3}$. Cita primero la condena de 1931 contra Al Capone por fraude fiscal cuando el origen de la renta no podía ser otro que delictivo ${ }^{4}$. Sin embargo, en 1946 en el caso Commissioner vs. Wilcox se entendió que la malversación no podía dar lugar a la consideración de renta gravable, puesto que el concepto de renta exige un derecho sobre ella y la ausencia de la obligación de restituirla, lo que no sucede en el supuesto del objeto de la malversación. Por el contrario, en 1952 la sentencia del caso Rutkin vs. EEUU entendió que sí era tributable la renta procedente de una extorsión, pues este delito sí genera un control real sobre los fondos, a diferencia de lo que ocurre con la malversación. En 1961 se dictó la sentencia del caso James vs. EEUU donde se fija, en opinión del citado autor, la doctrina definitiva sobre el tema considerando, quizá primando el aspecto económico sobre el estrictamente jurídico, que no hay intención de devolver los fondos obtenidos ilegalmente; de hecho, el sujeto disfruta de su valor económico, por lo que sí deben tener la consideración de renta gravable, y si finalmente estos fondos se devolvieran tendría lugar la correspondiente deducción tributaria. Finalmente el criterio se endurece aún más en 1989 cuando la sentencia del caso Wood vs. EEUU consideró que el comiso no debe dar lugar a la deducción, puesto que tiene naturaleza de pena y la deducibilidad anularía este carácter.

\section{Europa}

El Derecho europeo ha sido mucho más reacio a pronunciarse sobre este tema, si bien en fechas más recientes en varios países se ha resuelto en sentido favorable a la tributación.

En Italia está expresamente prevista la tributación por la ganancia ilícita, incluido el ilícito penal. Así, el art. 14.4 de la Ley 537/1993, de 24 de

2 S. Bacigalupo Saggese, Ganancias ilícitas y Derecho penal, Madrid, Ramón Areces, 2002, p. 8.

3 P. M. Herrera Molina, Fiscalidad de los actos ilícitos, Madrid, Instituto de Estudios Fiscales, 2003, pp. 63 y ss.

${ }^{4}$ El 24 de octubre de 1931 Alphonse Gabriel Capone fue condenado a once años de prisión por fraude fiscal. 
diciembre, establece que «en la categoría de renta [...] deben entenderse comprendidas, como en ella clasificables, las ganancias derivadas de hechos, actos o actividades calificables como ilícito civil, penal o administrativo, siempre que no estén ya sujetas a embargo o decomiso» ${ }^{5}$.

En Alemania el Abgabenordnung (código tributario) considera irrelevante si el comportamiento que da lugar al hecho imponible es contrario a un mandato o prohibición $(\mathbb{S} 40 \mathrm{AO})^{6}$, es decir, que se opta también por la tributación de las ganancias aunque sean ilícitas. En la jurisprudencia alemana se encuentran ejemplos como la venta de objetos robados, que se considera tributable como actividad económica, o la extorsión y el pago de comisiones ilegales, tributables como «otros ingresos» ${ }^{7}$.

En Francia la jurisprudencia del Consejo de Estado considera que el dinero y bienes obtenidos con actividades delictivas como el hurto, la estafa o la apropiación indebida están sometidas al impuesto sobre la renta, en general como «beneficios no comerciales» ${ }^{8}$.

Por tanto, en el Derecho comparado encontramos ejemplos de tributación por ganancias ilícitas.

\section{JURISPRUDENCIA}

\section{Caso Nécora}

Punto obligado de partida en la tributación de las ganancias ilícitas es la SAN de 27 de septiembre de $1994^{9}$, dictada como consecuen-

5 Art. 14.4 de la Ley 537/1993, de 24 de diciembre: «Nelle categorie di reddito di cui all'articolo 6, comma 1, del testo unico delle imposte sui redditi, approvato con decreto del Presidente della Repubblica 22 dicembre 1986, n. 917, devono intendersi ricompresi, se in esse classificabili, i proventi derivanti da fatti, atti o attivita' qualificabili come illecito civile, penale o amministrativo se non gia' sottoposti a sequestro o confisca penale».

6 \$40 AO: «Für die Besteuerung ist es unerbeblich, ob ein Verbalten, das den Tatbestand eines Steuergesetzes ganz oder zum Teil erfüllt, gegen ein gesetzliches Gebot oder Verbot oder gegen die guten Sitten verstößt». Vid. también C. Mallada FERnÁNDEZ, Blanqueo de capitales y evasión fiscal, Valladolid, Lex Nova, 2012, p. 157.

7 P. M. Herrera Molina, Fiscalidad..., op. cit., pp. 57 y s.

${ }^{8}$ Ibid., p. 62. Se refiere a las ganancias no comerciales el art. 92.1 del Code Général des Impôts: «Sont considérés comme provenant de l'exercice d'une profession non commerciale ou comme revenus assimilés aux bénéfices non commerciaux, les bénéfices des professions libérales, des charges et offices dont les titulaires n'ont pas la qualité de commerçants et de toutes occupations, exploitations lucratives et sources de profits ne se rattachant pas à une autre catégorie de bénéfices ou de revenus».

9 SAN (Sala de lo Penal, Sección 3. .) de 27 de septiembre de 1994 (ROJ 2/1994). 
cia de la conocida Operación Nécora. El matrimonio formado por Laureano Oubiña y Ester Lago fue condenado no por tráfico de drogas (que no resultó probado por declararse nulas las escuchas telefónicas), sino por receptación, por haberse lucrado con ese tráfico y, asimismo, por dos delitos de fraude fiscal (IRPF de los periodos impositivos $1987 \mathrm{y}$ 1988) por no haber declarado estas ganancias con las que además hicieron diversas operaciones económicas posteriores que les reportaron pingües beneficios. Se debe partir de esta sentencia, pues es la primera en España en tratar este tema ${ }^{10}$, y así lo dice la propia sentencia: «no existe ningún pronunciamiento judicial, no lo hemos hallado al menos», e incluso se añade: «no habiéndose ocupado tampoco la doctrina científica del mismo».

El fundamento de Derecho $70 .^{\circ}$ de la sentencia argumentaba esta condena considerando que «los beneficios procedentes de actividades ilícitas están sujetas (sic) a tributación a través del IRPF y a través del impuesto de sociedades, porque constituyen renta, no existiendo precepto alguno que condicione la fiscalidad de la misma a que la actividad que origine (sic) sea o no legal». Continúa diciendo: «el principio de igualdad ante el impuesto prohíbe un tratamiento fiscal más favorable a quien viole el derecho que a quien lo respete», y añade: «pudiendo además materializarse con tales beneficios inversiones diversas que a su vez van a producir nuevos beneficios, y si se optare por la no tributación del dinero producido por actividad económica ilegal, se estaría estableciendo una barrera que haría prácticamente imposible introducir la fiscalidad en esa cadena de inversiones».

Comentando esta sentencia dice Mallada Fernández que «en ningún modo se le está dando un tratamiento más favorable a los fondos obtenidos ilegalmente, ya que con el decomiso, los autores del delito, posibles contribuyentes, pierden su supuesta capacidad económica» ${ }^{11}$. Sin embargo, no parece correcta esta afirmación, pues el mero decomiso es un tratamiento mucho más favorable que la condena por fraude fiscal, ya que el primero sólo supone la pérdida del dinero ganado delictivamente, pero la segunda supone pena de prisión, pérdida de una parte de ese dinero que se deberá pagar en concepto de responsabilidad civil, más una multa pro-

${ }^{10}$ C. Mallada Fernández, Blanqueo de capitales..., op. cit., p. 143; E. RuIZ de ERenchun ARteCHE, «¿Hay que declarar a la Hacienda Pública los ingresos delictivos?», Revista Aranzadi Doctrinal, núm. 6 (2009), p. 1, e ÍD., «Caso Urralburu», Laleydigital360, núm. 13.455 (2011), p. 2.

${ }^{11}$ C. Mallada Fernández, Blanqueo de capitales..., op. cit., p. 146. 
porcional que puede alcanzar hasta el séxtuplo de la cuantía defraudada (art. $305 \mathrm{CP}$ ), por lo que el mero decomiso sería mucho más beneficioso que la condena por fraude fiscal. Además, esta condena no excluye el decomiso porque si se condena por el delito previo, se debe imponer también el decomiso de las ganancias.

Pese a que la sentencia se recurrió en casación por inaplicación del art. 8.3 CP, es decir, por no considerar que entre la receptación y el fraude fiscal haya un concurso de leyes que se deba resolver por la regla de la absorción, el Tribunal Supremo ${ }^{12}$ no tuvo, en realidad, ocasión de pronunciarse sobre la cuestión. El motivo fue que revocó la sentencia de la Audiencia Nacional en lo referente a la condena por receptación (porque se condenó por este delito por unas declaraciones testificales obtenidas por comisión rogatoria en Bélgica en las que no pudo participar el letrado de la defensa), por lo cual no llegó a tratarse el problema concursal, confirmándose sin más las condenas por los dos delitos de fraude fiscal, ya que no se habían recurrido estas condenas por otros motivos.

\section{Caso Roldán}

La segunda vez que la jurisprudencia española se pronunció sobre este particular fue a raíz del llamado caso Roldán, en el que la Audiencia Provincial de Madrid ${ }^{13}$ condenó al que fuera director general de la Guardia Civil por delitos de estafa, cohecho, malversación, así como por cinco delitos de fraude fiscal por no declarar los ingresos reportados por sus actividades delictivas y por las operaciones posteriores que había realizado con ellos. El recurso de casación de la defensa se interpuso por inaplicación del art. 8.3 CP, por vulneración del principio ne bis in idem y por vulneración del derecho a no declarar contra uno mismo. En este caso el Tribunal Supremo sí tuvo ocasión de pronunciarse ${ }^{14}$ sobre todo aquello sobre lo que no se pudo pronunciar en el caso Nécora. Rechazó que se tratase de un concurso de leyes argumentando que los delitos de estafa, cohecho y malversación se cometieron con acciones distintas de las que dieron lugar a los delitos de fraude fiscal, consistentes éstas en la presentación de declaraciones tributarias fraudulentas, además de hechas las unas y las otras en

12 STS (Sala de lo Penal) núm. 649/1996, de 7 de diciembre.

${ }^{13}$ SAP de Madrid (Sección 6. ${ }^{a}$ ) núm. 75/1998, de 24 de febrero.

14 STS (Sala de lo Penal) núm. 1493/1999, de 21 de diciembre. 
momentos temporales diferentes y siendo también distintos los bienes jurídicos protegidos, por lo que el concurso se consideró material y no formal. Esto mismo dio lugar a que no se entendiera quebrado el principio ne bis in idem. Rechazó también la conculcación del derecho a no declarar contra uno mismo, puesto que se trata de un derecho referente «a las contribuciones del imputado o de quien pueda razonablemente terminar siéndolo y solamente a las contribuciones que tienen un contenido directamente incriminatorio». En otras palabras, se le pide una declaración tributaria, lo que no supone declararse autor de ningún delito. Finalmente confirmó las condenas por fraude fiscal aludiendo precisamente a la sentencia del caso Nécora dictada por la Audiencia Nacional, mencionando expresamente el principio de igualdad y la cadena de inversiones al margen de la fiscalidad que se generaría de no seguirse este criterio, avalando así el Supremo el criterio de la Audiencia Nacional.

Comentando esta sentencia dice Herrera Molina que no lleva a cabo una distinción necesaria: por un lado, el dinero obtenido por el condenado mediante estafa y malversación, y, por otro, el obtenido mediante cohecho. El autor entiende necesaria esta distinción, pues en el primer caso la sentencia debe ordenar la restitución al legítimo propietario y, por tanto, no cabe sujetar dichas rentas a tributación. Sin embargo, en el segundo supuesto, el del cohecho, el pagador no tiene derecho a la restitución, cabe el decomiso, pero «no es una consecuencia automática de la condena y no atribuye un derecho de propiedad al Estado con anterioridad al momento en que se dicte la sentencia», por lo que en este supuesto sí debe someterse la renta a tributación ${ }^{15}$. No comparto este criterio sobre todo porque no aprecio diferencias entre un supuesto y otro suficientemente importantes como para motivar un tratamiento dispar que excluya la tributación en el caso del dinero obtenido mediante estafa o malversación. La sola obligación de restituir no parece que deba motivar la no tributación (obsérvese que la obligación de tributar casi en todo supuesto precederá a la condena penal). La posibilidad de que ésta se produzca no debe eximir de tributación a quien haya obtenido la ganancia por vía delictiva. Qué sucede si finalmente no se restituye, por ejemplo, por renuncia del agraviado a la responsabilidad civil o por reserva de la acción para ejercitarla en el orden civil y que finalmente no se ejercita, o simplemente porque el condenado no paga voluntariamente la responsabilidad civil y carece de bienes embargables. Es cierto que en caso de

15 P. M. Herrera Molina, Fiscalidad..., op. cit., pp. 73 y ss. 
estafa o malversación el agraviado no habrá perdido nunca la propiedad, pero esto será así si finalmente recupera el objeto del delito, porque de no recuperarlo carece de sentido considerarlo propietario de aquello que nunca recuperará. Que la propiedad del objeto del delito pase a quien ha cometido el delito es una posibilidad que puede evitarse, pero mientras esto no ocurra no hay razón para considerar que no se debe tributar por esta ganancia. En relación con el otro argumento esgrimido, que el decomiso no sea consecuencia automática de la condena, se debe señalar que la restitución de la cosa tampoco es automática. Es más, el decomiso debería ser automático por aplicación del art. 127.1 CP y sólo por error judicial no se decomisarán las ganancias del delito, mientras que la restitución de la cosa depende de la voluntad del perjudicado, según lo dicho anteriormente. No puedo estar de acuerdo, por tanto, con esta distinción; entiendo que debe someterse la renta a tributación en todo caso, aunque más adelante veremos, con más desarrollo, los motivos por los que Herrera Molina lleva a cabo esta distinción.

Sobre el principio de igualdad invocado por esta sentencia y ahondando en las operaciones que el condenado realizó con el dinero de origen ilícito, dice Luzón Cánovas ${ }^{16}$ que «la aplicación de esta doctrina evita crear injustificadas situaciones de privilegio, ofreciéndonos el propio caso Roldán un ejemplo muy claro. Luis Roldán adquirió en 1991 un inmueble para su vivienda particular en Madrid por un precio de 135 millones de pesetas, si bien en la escritura sólo se hizo constar 60 millones. Una vez comprobado que los 75 millones de dinero negro habían sido pagados por el comprador mediante cheques bancarios al portador, procedentes tanto de comisiones ilegales satisfechas por empresas constructoras como de la cuenta de fondos reservados que la Secretaría de Estado de interior tenía en el Banco de España, resultaría verdaderamente injusto que al vendedor, en este caso la compañía "Platerías 4, S. A.", se le practicara la correspondiente liquidación y se le obligara a satisfacer los impuestos dejados de ingresar, en tanto que el comprador pudiera eludir su responsabilidad alegando la ilicitud del origen de los medios de pago utilizados».

16 A. LuZÓn CÁNOVAS, «Aspectos constitucionales de la tributación por rentas de origen delictivo», Laleydigital360, núm. 5.061 (2005), p. 8. 


\section{Caso Urralburu}

Finalmente el Tribunal Supremo se ha pronunciado una vez más sobre esta cuestión en el llamado caso Urralburu, en el que la Audiencia Provincial de Navarra ${ }^{17}$ condenó al que fuera presidente de la Comunidad Foral, Gabriel Urralburu, y al consejero de Obras Públicas, Antonio Aragón Elizalde, por delito continuado de cohecho (por cobrar comisiones por adjudicaciones de obras públicas en Navarra), y, además, por no declarar el dinero obtenido de este modo se les condenó también por dos delitos de fraude fiscal al primero y por uno solo al segundo.

Recurrida la sentencia en casación, si bien el Tribunal Supremo ${ }^{18}$ volvió a rechazar la vulneración del derecho a no declarar contra uno mismo citando expresamente la sentencia del caso Roldán, sin embargo, revocó las condenas por fraude fiscal dictadas contra ambos condenados. El Tribunal entendió que aunque no es incompatible la condena por delitos que generan beneficios económicos con la condena por delitos fiscales por no declarar los incrementos patrimoniales que generen indirectamente esos delitos, no sucede lo mismo cuando se trata de beneficios generados de manera directa, como es el supuesto que nos ocupa. Es decir, en los casos Nécora y Roldán los beneficios obtenidos se reinvirtieron y se obtuvieron más beneficios, y, por tanto, cabe la condena por el delito que aportó dichos beneficios, pero también por no declarar los beneficios posteriormente obtenidos con la reinversión de ellos. Sin embargo, en el caso Urralburu los beneficios obtenidos mediante sobornos no se habían reinvertido y, por tanto, no puede castigarse por un delito lucrativo como el cohecho y además por no declarar dicho lucro. El propio Tribunal concreta su doctrina estableciendo tres requisitos para que quepa aplicar este concurso de leyes:

1. Que los ingresos que genere el delito fiscal procedan de modo directo e inmediato del delito anterior ${ }^{19}$.

2. Que el delito inicial sea efectivamente objeto de condena.

17 SAP de Navarra (Sección 1.å) núm. 164/1998, de 7 de septiembre.

18 STS (Sala de lo Penal) núm. 20/2001, de 28 de marzo.

19 A. LuZÓn CÁnovas, «Aspectos constitucionales...», op. cit., p. 15, se sorprende de esta exigencia, pues en el caso Urralburu no todos los ingresos procedían de modo directo e inmediato de un delito. La sentencia recurrida hablaba de que «parte del origen de estos flujos proceda de la comisión del delito de cohecho» y la sentencia del Supremo utilizó la expresión «la práctica totalidad». 
3. Que la condena penal del delito fuente incluya el comiso de las ganancias obtenidas en el mismo o la condena a su devolución como responsabilidad civil ${ }^{20}$.

La sentencia también plantea el problema de que no exista certeza de la condena por el delito fuente hasta la firmeza de la misma, y, por tanto, hasta ese momento cabría la posibilidad de condena por fraude fiscal, pero tal cosa sólo podrá suceder si se ha instruido y formulado acusación por él. Por ello el propio Tribunal, al tratar el punto segundo reseñado, considera que «en consecuencia, los delitos fiscales deducidos de incrementos patrimoniales que podrían tener origen delictivo deben ser en todo caso objeto de investigación y acusación como delito contra la hacienda pública, pues solamente si el delito del que proceden los ingresos es finalmente objeto de condena podrá absorber las infracciones fiscales, pero si no lo es por cualquier causa, los delitos fiscales deberán ser autónomamente sancionados». A renglón seguido la sentencia añade esta sorprendente afirmación: «la procedencia ilícita de los bienes no puede constituirse en un beneficio o privilegio para el defraudador». Sorprende, pues esta doctrina precisamente establece ese privilegio: lo ganado delinquiendo debe tributarse, pero si no se tributa, aunque se supere el umbral delictivo, queda exento de pena si se condena por el delito fuente.

En ocasiones podrá suceder que la absolución por el delito fuente perjudique al reo, que verá cómo se le condena por un delito como el fraude fiscal que puede ser más grave que el delito del que proceda el dinero. Dicho de otro modo, aquel a quien se le detecte incremento patrimonial no justificado saldrá perjudicado si reconoce que lo ha recibido en negro y beneficiado si afirma que lo hurtó, pues la pena máxima por el hurto será de tres años de prisión (por aplicación de la agravante del art. 235.1.5. $\mathrm{CP}$ ), lejos de los cinco o hasta seis años que pueden imponerse por fraude fiscal (arts. 305 y 305 bis CP), y se ahorrará la multa. En otras palabras, dejando exento de pena el fraude fiscal de la ganancia delictiva se estimula a cualquier defraudador fiscal a reconocer, aunque no sea cierto, un supuesto delito que le haya reportado ese lucro (con tal de que sea de menor gravedad que el fraude fiscal), si bien en la práctica no es ésta una estrategia a la que se suela recurrir por la defensa en los procesos por delito de fraude fiscal.

${ }^{20} \mathrm{Ibid}$., p. 16, considera que este tercer requisito deja inaplicable la sanción penal por fraude fiscal cuando el origen de la ganancia es delictivo, pues la condena por este delito siempre dará lugar al decomiso de las ganancias. 
La sentencia también parece errónea en cuanto que considera tributables las operaciones posteriores, y si no se tributa por ellas, el hecho será punible, pero si casi cualquier operación posterior que se pueda concebir, hecha con capitales de origen delictivo, es constitutiva de delito de blanqueo de capitales (art. $301 \mathrm{CP})^{21}$, aplicando esta doctrina también debería quedar exenta de sanción la operación si se condena por blanqueo y se ordena el decomiso. En fin, considero evidente, por los motivos expuestos, que la ganancia obtenida delinquiendo debe declararse, y de no ser así, si se alcanza la cuantía delictiva se estará cometiendo también un delito de fraude fiscal por el que deberá dictarse sentencia condenatoria. Al mantenerse la condena sólo por el delito de cohecho, la sentencia curiosamente concluye esta argumentación lamentándose de la «insuficiente» pena (a la sazón cuatro años de prisión) que puede imponerse «por estos gravísimos supuestos de cohecho».

No sólo desde el punto de vista práctico el resultado es funesto, sino que desde el punto de vista teórico tampoco es sostenible esta doctrina. El concurso de leyes existe cuando unos mismos hechos pueden castigarse aplicando dos preceptos distintos del Código y en este supuesto no sucede, porque no se trata de los mismos hechos. Por un lado, el cohecho, que consiste en soborno, es decir, en obtener dinero un funcionario público a cambio de realizar una acción u omisión concreta en el ejercicio de su cargo (art. 419 CP). Por otro, el fraude fiscal, consistente en eludir el pago de tributos (art. $305 \mathrm{CP}$ ). Los hechos son clarísimamente distinguibles e incluso tienen lugar en fechas separadas al menos por seis meses, ya que este tipo de incrementos patrimoniales encajan en el IRPF, cuyo plazo de pago voluntario concluye el 30 de junio del año siguiente a aquel en que se produjo la ganancia. Así pues, al menos seis meses mediarán entre el cohecho y el fraude fiscal ${ }^{22}$. Esta distinción se describe nítidamente, como antes vimos, en la sentencia del caso Roldán. Me parece, por tanto, incomprensible que la sentencia ahora comentada considere aplicable el art. $8 \mathrm{CP}$ sin dar ninguna explicación de por qué entiende que dos hechos sucedidos en fechas tan distantes, atacando bienes jurídicos diferentes, obedeciendo

${ }^{21}$ Vid. R. De Mosteyrín SAmpalo, «El delito de blanqueo de capitales a la luz de la normativa internacional sobre la materia», Anuario de Derecho Penal y Ciencias Penales, t. 69, fasc. 1 (2016), pp. 375-407.

${ }^{22}$ El delito de fraude fiscal se entiende cometido el último día del plazo de pago voluntario. Así, STS (Sala de lo Penal) núm. 1590/2003, de 22 de abril: «La realización de la conducta típica con toda su eficacia ofensiva en los dos aludidos planos ya se habría producido en el último momento hábil para realizar el pago del tributo [TS SS. 26 Jul. 1999 (RJ 1999, 6685) y 6 Nov. 2000 (RJ 2000, 9271)]». 
a resoluciones delictivas tan claramente distinguibles y sin que uno implique en absoluto el otro se consideran subsumibles en el concurso de leyes.

Ruiz de Erenchun Arteche rechaza que se trate de un concurso de leyes, por un lado, porque no se trata de un solo hecho, sino de dos, y, por otro, porque esta consideración parte de la base de que existe obligación de tributar por las ganancias ilícitas, ya que de lo contrario no habría concurso de leyes, puesto que no sería de aplicación el art. 305 CP. Este autor niega que exista esta obligación de tributar, pues la ganancia obtenida delinquiendo le corresponde a su legítimo propietario y, en su defecto, al Estado por vía del decomiso, pero señala que como la sentencia comentada entiende que existe un concurso de leyes, está de este modo considerando que existe obligación de tributar por las ganancias ilícitas y que habría delito en caso de no tributar por ellas, pues, de lo contrario, de no existir esta obligación no habría concurso, ya que no habría dos leyes aplicables, concretamente no sería aplicable el art. $305 \mathrm{CP}$ al no existir obligación de tributar. Por otro lado, como la sentencia considera también que, aun habiendo delito, no se debe condenar si existe decomiso, parece olvidar que la acción civil es disponible y que será, por tanto, el perjudicado quien decidirá si se condena al reo por dos delitos o por uno. Concluye que el Tribunal Supremo debe corregir esta tesis adaptándola al principio de capacidad económica, lo que excluirá el delito de fraude fiscal si se aplica la consecuencia jurídica que determina la ausencia de capacidad económica, es decir, la restitución al propietario o el decomiso ${ }^{23}$.

Herrera Molina tampoco se muestra favorable a la tesis del concurso de leyes. Entiende que para ello «el delito fiscal debería estar lógicamente comprendido en el supuesto de hecho del delito de estafa frente a una persona distinta de la Hacienda Pública, o viceversa» ${ }^{24}$. Parece desacertada esta expresión, pues para que fuera el delito fiscal una modalidad de estafa tendría que estar previsto el delito de estafa precisamente frente a la Hacienda Pública, si no existe esta previsión en el delito de estafa es precisamente porque existe el fraude fiscal ${ }^{25}$. Si existiera esa previ-

${ }^{23}$ E. Ruiz de ERenchun Arteche, «Caso Urralburu», op. cit., pp. 5 y ss.

${ }^{24}$ P. M. Herrera Molina, Fiscalidad..., op. cit., p. 78. El inciso final «o viceversa» me resulta incomprensible. No entiendo si se refiere a que la otra posibilidad sería que el delito de estafa estuviera comprendido en el delito de fraude fiscal, pero contra persona distinta de la Hacienda Pública. Si es así, no sólo nos encontraríamos ante un curioso delito, sino que además tampoco formaría concurso de leyes con el fraude fiscal tradicional.

${ }^{25}$ Sí existe una previsión semejante en el delito de alzamiento de bienes en el párrafo segundo del art. 257.3 CP, pero no existe concurso de leyes con el fraude fiscal, pues la acción es diferente. 
sión podría tratarse de un concurso de leyes ${ }^{26}$ a resolver de acuerdo con la regla de especialidad del art. 8.1 CP, por lo que se aplicaría el fraude fiscal y no la estafa a la Hacienda Pública. Incluso no existiendo expresamente el delito de estafa a la Hacienda Pública cabe considerar concurso de leyes entre la estafa tal como está prevista en nuestro Código si la perjudicada es la Hacienda Pública, por una parte, y el fraude fiscal (siempre que exista acto de disposición), por otra, y este concurso se resolverá igualmente aplicando la regla de la especialidad a favor del fraude fiscal. Pero la cita transcrita viene a decir que el concurso de leyes existe cuando la perjudicada por estafa es una persona distinta a la Hacienda Pública, afirmación que no entiendo correcta. La perjudicada debe ser la Hacienda Pública para que pueda existir concurso de leyes, pues en otro caso no se tratará de un mismo hecho calificable de dos formas distintas, sino de dos hechos diferentes que formarán un concurso real. En cualquier caso, no es esto lo que sucede en el caso Urralburu, en el que existe un delito de cohecho y otro de fraude fiscal. El inciso parece tan erróneo que quizá pueda tratarse de una errata. El citado autor continúa diciendo que se trata de un concurso medial, pero no da explicaciones al respecto y parece que se vuelve a equivocar. El fraude fiscal no puede ser un medio para cometer el cohecho, que ya estaba cometido previamente, de modo que entendemos que considera medio el cohecho. Sin embargo, que la ganancia defraudada proceda del cohecho no quiere decir que éste sea un medio para cometer aquél, porque la intención del autor no es cometer un fraude fiscal para el que previamente deba cometer un cohecho. Muy al contrario, su intención es cometer un cohecho y posteriormente, y para no ver mermada su ganancia, decide cometer el fraude fiscal. Por todo ello insisto en que se trata de un concurso real de delitos.

Hace Herrera Molina una crítica más a esta sentencia, y es considerar que el posible fraude fiscal lo era al IRPF cuando, según la propia sentencia, las ganancias se habían generado mediante delito de cohecho, considerando más apropiada la tributación por el Impuesto sobre Donaciones. Considera que el error se debe a que en los informes de la inspección tributaria se entendió que se trataba de ganancias patrimoniales no justificadas y de origen desconocido, pero una sentencia que determina el origen de las ganancias en delitos de cohecho no es razonable que al mismo tiem-

${ }^{26}$ La estafa requiere por parte del perjudicado «un acto de disposición» que no suele existir en el fraude fiscal, aunque sí en algunas modalidades como el llamado fraude del IVA tipo carrusel. Por tanto, sólo en algunas modalidades de fraude fiscal podría entenderse que existe este concurso de leyes con la estafa. 
po las considere de origen desconocido. Aunque en la voluntad del autor del cohecho no está el ánimo de liberalidad, pues espera obtener una contraprestación a cambio de su dádiva, sin embargo, el sujeto pasivo no queda jurídicamente obligado a esta contraprestación, por lo que la dádiva puede tener ciertos tintes de donación. Este autor aclara que no será de aplicación automática el Impuesto sobre Donaciones en los supuestos de cohecho, ya que se deberá valorar el nexo entre la dádiva y la contraprestación, pero sí lo entiende aplicable en todo caso al cohecho pasivo cuando se lleva a cabo por la mera consideración al cargo o para la consecución de un acto no prohibido de los actuales arts. 420 y $422 \mathrm{CP}^{27}$.

También Luzón Cánovas considera erróneo que nos encontremos ante un concurso de leyes: «desde el punto de vista de la acción, los delitos que dan origen a la ilegal ganancia [...] han sido ejecutados por el agente mediante hechos anteriores, independientes y claramente separados del momento de efectuar las correspondientes declaraciones fiscales o de omitir éstas». Argumenta que el bien jurídico protegido es distinto en el fraude fiscal y en los delitos origen de la ganancia, y citando la sentencia del caso Roldán afirma que «de la tríada de identidades que integran la vulneración del principio non bis in idem no concurren ni la identidad de hechos ni la de fundamento» ${ }^{28}$. Concluye este autor que la sentencia del caso Urralburu «no representa un avance respecto de la más correcta que puso fin al caso Roldán, ya que dispone un inexistente concurso de normas frente al genuino concurso real de delitos que se establece entre el delito fiscal y el delito patrimonial que da origen al incremento patrimonial» ${ }^{29}$.

Aunque la jurisprudencia analizada no se ha planteado la posibilidad de considerar el fraude fiscal como un acto posterior impune en relación con el delito previo, entiendo que tampoco sería aplicable al caso. Cierto es que quien asesta a otro una puñalada no incurre en omisión del deber de socorro cuando a continuación huye del lugar sin prestarle auxilio, porque exigirle tal cosa supondría esperar una conducta que es contraria a la que acaba de realizar. Por tanto, el legislador al fijar la pena para la puñalada ya prevé que el autor no va a socorrer a la víctima después, y el castigo previsto es el que se consideró adecuado para todo el desvalor generado. Sin embargo, en el supuesto de fraude fiscal subsiguiente a un delito lucrativo no es así. Tributar por el dinero ganado delictivamente no es una conduc-

\footnotetext{
${ }^{27}$ P. M. Herrera Molina, Fiscalidad..., op. cit., pp. 115 y ss.

28 A. LuZÓN CÁNOvAS, «Aspectos constitucionales...», op. cit., pp. 13 y ss.

${ }^{29}$ Ibid., p. 17.
} 
ta contraria a la realizada anteriormente (al menos no más contraria que tributar por lo ganado honradamente). Se puede cometer un delito lucrativo y a continuación tributar por él sin que con esta última acción estemos deshaciendo la anterior, y el legislador al castigar el delito previo no tuvo por qué tener en cuenta que el autor no fuese después a tributar por la ganancia obtenida, por lo que el desvalor generado no se ve restaurado del todo por la sola imposición de la pena prevista para el delito fuente.

Quizá el mayor reproche que se puede realizar a la teoría de la tributación de las ganancias delictivas, como luego se verá, es que con ello se estará revelando el delito del que proceden estas ganancias, y por eso se ha planteado reiteradamente que conculca el derecho a no declarar contra uno mismo. Sin embargo, esto no es cierto. La declaración no tiene por qué suponer revelar el delito del que procede la ganancia. Se puede consignar el incremento patrimonial en la declaración de la renta como ganancias y pérdidas patrimoniales sin dar más datos al respecto, e incluso se puede pagar la cuantía que proceda sin presentar siquiera la declaración tributaria, y con ello se estaría evitando el delito sin revelar en absoluto la fuente. Si como consecuencia del exceso de pago se inicia un procedimiento de inspección tributaria, cosa que se nos antoja poco probable, ése será el momento, y no antes, de no declarar para no incriminarse. Lo que nunca se deberá hacer será atribuir la ganancia a fuente diferente de la real, pues en ese caso se incurriría en delito de blanqueo de capitales al ocultar la verdadera naturaleza u origen del capital (art. 301 CP). En fin, puede suceder que quien se ha lucrado delinquiendo no quiera incurrir en un delito más y para ello tribute por las ganancias, o puede suceder, por el contrario, que no le importe incurrir en un delito más con tal de no ver mermado su patrimonio y para ello eluda el pago de tributos. En este segundo supuesto se generará un mayor desvalor de acción y de resultado ante el que el Derecho penal tiene como respuesta el castigo por fraude fiscal.

\section{Sentencias posteriores}

A pesar de todo lo dicho, la «doctrina Urralburu» parece haber calado hondo en la jurisprudencia española. La STS núm. 1113/2005 ${ }^{30}$ desestimó un recurso de casación interpuesto por el abogado del Estado en el que se pretendía que a quien se había condenado en la instancia por apro-

${ }^{30}$ STS (Sala de lo Penal) núm. 1113/2005, de 15 de septiembre. 
piación indebida se le condenara también por fraude fiscal, por no declarar el dinero del que se había apropiado y del que resultaba una deuda tributaria que superaba la cuantía delictiva. El recurso se desestimó porque el abogado del Estado introdujo sorpresivamente este delito al elevar a definitivas las conclusiones en el juicio oral sin que en la calificación provisional se hiciera referencia a él, argumento contra el que nada cabe objetar y que por sí sólo bastaría para desestimar el recurso. Pero también se añade que «esta Sala Casacional ya ha declarado que tales incrementos patrimoniales cuando son consecuencia directa de un delito no pueden servir, a su vez, para conformar una omisión tributaria que configure el delito fiscal, al menos si no ha existido una posterior transformación en otros activos patrimoniales». Se citan expresamente la sentencia del caso Urralburu, incluso reproduciendo la parte de dicha sentencia en que se recogen los tres requisitos para que resulte de aplicación esa doctrina, y la del caso Roldán, argumentando que la primera complementó la línea ya declarada por la segunda, aunque, según se ha visto, ésta motiva perfectamente y con argumentos que aquélla soslaya que no se trata de un concurso de leyes.

También mantiene esa línea la STS núm. 769/2008 ${ }^{31}$ que confirmó otra de la Audiencia Nacional en que se absolvía a quienes en otro procedimiento fueron condenados por blanqueo de capitales y ahora eran acusados de fraude fiscal por no declarar el dinero obtenido en ese blanqueo. El Tribunal Supremo mantiene la absolución por fraude fiscal citando expresamente la sentencia del caso Urralburu, de la que también reproduce la parte en que se citan los tres requisitos para que resulte de aplicación dicha doctrina. Todo ello a pesar de que, según recoge la sentencia, el recurso del abogado del Estado argumentaba que «no nos hallamos ante una única acción doblemente penada, sino ante una actividad delictiva plural en que la sanción de alguna de las conductas o los efectos de la misma no absorbe todo el desvalor y reproche que la totalidad de la conducta merece», es decir, que no se trata de un concurso formal, sino material. Sin esgrimir un sólo argumento por el que la Sala considere que el concurso es formal y no material, se vuelven a citar las sentencias Roldán y Urralburu y se desestima el recurso. El recurso también se interpuso por el fiscal, que aparte de otro motivo que aquí no nos interesa, argumentaba que la sentencia dictada por blanqueo de capitales en el otro procedimiento todavía no era firme, por lo que en previsión de lo que pudiera suceder debía dictarse condena por fraude fiscal. No obstante, la Sala

\footnotetext{
${ }^{31}$ STS (Sala de lo Penal) núm. 769/2008, de 30 de octubre.
} 
consideró que este retardo en adquirir firmeza no debe perjudicar al reo, aunque como a tiempo de dictar sentencia sí había adquirido ya firmeza la sentencia condenatoria por blanqueo (confirmada), siempre quedará la duda de si habría sido otra la resolución de la Sala de haber estado aún pendiente la firmeza a tiempo de resolver. Obsérvese que, pese a la firmeza de la otra sentencia, no se desestimaron los recursos del fiscal y del abogado del Estado por cosa juzgada, por lo que la Sala no parece tener muy claro qué es un concurso de leyes, o al menos no estaba muy convencida de encontrase ante tal concurso.

Hay quien cita también ${ }^{32}$ como supuesto de continuidad de esta doctrina la SAP de Córdoba núm. 607/200633, desestimatoria del recurso de la defensa que pretendía la absolución argumentando que el dinero podría ser de origen ilícito. La sentencia cita los casos Roldán, Urralburu y la antes comentada STS núm. 1113/2005 para afirmar que, aunque fuera ése el origen del dinero, no por ello queda la condenada exenta del deber de declarar. No obstante, como en este supuesto la condena fue sólo por fraude fiscal y por ningún otro delito, no se pronuncia la Sala sobre el concurso formal o material que pudiera darse entre el delito fuente y el de fraude fiscal, por lo que poco aporta a esta cuestión salvo que confirma el deber de declarar por las ganancias ilícitas, cosa que la sentencia del caso Urralburu tampoco puso en duda.

Finalmente cabe citar la SAP de Barcelona de 12 de febrero de $2008^{34}$ que condenó a Javier de la Rosa por la multimillonaria descapitalización de la sociedad anónima Grand Tibidabo. Los hechos consisten, en resumen, en que el condenado, al presentar la declaración del Impuesto sobre Sociedades de 1991, consideró gastos deducibles tres facturas de supuestos gastos de intermediación en unas operaciones realizadas, cuando en realidad dichas operaciones tenían por única misión arruinar la sociedad en provecho propio y de sus compinches. Fue condenado por apropiación indebida; la cuestión es si se le debió condenar también por fraude fiscal. No se le condenó y aquí la Audiencia, tras citar las sentencias de los casos Nécora, Roldán y Urralburu, entiende que no son de aplicación porque se da en este supuesto una circunstancia diferente que impide aplicar la misma teoría: aquí el fraude lo fue al Impuesto sobre Sociedades; además, en una sociedad anónima en que los accionistas nada tenían que ver con el princi-

32 E. Ruiz de EREnChun Arteche, «¿Hay que declarar...», op. cit., p. 2.

33 SAP de Córdoba (Sección 1.a) núm. 607/2006, de 21 de noviembre.

34 SAP de Barcelona (Sección 2. ${ }^{a}$ ) núm. 1806/2008, de 12 de febrero. 
pal organizador de la trama. Por ello, si las operaciones delictivas realizadas por éste habían perjudicado a la sociedad, una condena por fraude fiscal volvería a perjudicarla al declararse la responsabilidad civil subsidiaria de dicha sociedad, es decir, que aquí la sociedad resulta al mismo tiempo obligada tributaria y perjudicada por el delito. Además, la Sala consideró que si la ley hace recaer la responsabilidad de lo que se haga en el seno de una persona jurídica en las personas físicas (en la era del societas delinquere non potest) es entendiendo que éstas actúan en provecho de aquélla, pero como en el supuesto que nos ocupa no ha sido así, sino que se ha actuado en contra de dicha sociedad, no cabe aplicar el «habitual automatismo del art. 15 bis del CP de 1973 [actual art. 31]».

Quizá esta sentencia intentó conseguir efectos de justicia material para amortiguar los efectos sobre los accionistas, porque no parece correcto absolver por estos motivos. Que los administradores actúen contra la sociedad no debe dar lugar a que se les exima de responsabilidad por fraude fiscal, pues ni el Código lo establece expresamente ni es de recibo abrir así una peligrosa puerta a la impunidad en un delito en que es fácil argumentar que se perjudica a una sociedad que, recuérdese, será siempre responsable civil subsidiaria, y en aquella época además responsable penal solidaria de la multa proporcional ${ }^{35}$. Si lo que se pretendía era obtener justicia material bastaba con aplicar la desafortunada doctrina Urralburu, ya que la misma sentencia condena por apropiación indebida, o incluso, ya que al parecer había voluntad de innovar, podría haberse desarrollado un sugerente argumento que, aunque la sentencia menciona, pasa por él de puntillas: «principios éticos no permiten convertir al Estado en receptador o partícipe del delito cometido». La sentencia no ahonda más en esta cuestión, pero esta falta de principios éticos se llama en Derecho penal delito de blanqueo de capitales (art. $301 \mathrm{CP}$ ). Se plantea aquí la pregunta de si cometería blanqueo el funcionario de Hacienda que reclame para el Estado dinero que sepa procedente de un delito. En mi opinión, no. Esto condenaría el dinero delictivo al abandono sin que nadie pudiera siquiera acercarse a él. La intervención del Estado sobre este dinero por la vía de la tributación, del decomiso o de la condena por responsabilidad civil debe considerarse que limpia el origen delictivo sin que se genere responsabilidad para los funcionarios por aplicación de la eximente del art. 20.7 CP. En realidad, como

35 Actualmente el Código Penal establece que en caso de resultar condenada la persona jurídica se le impondrá multa a ella directamente (art. 310 bis CP) y se podrá moderar, en su caso, con la de las personas físicas (31 ter.1 CP). 
señala Herrera Molina, subyace el mismo problema en todo supuesto de decomiso: «las ganancias se extirpan del tráfico delictivo para destinarse a financiar actividades a favor del interés general» por lo que «la supuesta inmoralidad del Estado se basa en premisas falsas» ${ }^{36}$.

Apréciese que el tema de la tributación de las ganancias ilícitas se planteó por primera vez (caso Nécora) en un supuesto de delito muy grave en que no se pudo aplicar pena elevada y que se ha planteado casi exclusivamente en supuestos periodísticos y graves. Esto pone de relieve que en la mente del operador jurídico no parece que esté la idea de la tributación de este tipo de ganancias, sino que más bien se recurre a ella para intentar imponer penas mayores en ciertos supuestos en que se pretende tratar con ejemplaridad casos en que la ley no prevé penas que se hallen a la altura de las circunstancias.

\section{DOCTRINA}

La doctrina española se ha ocupado poco de la tributación de las ganancias ilícitas; no obstante, exponemos a continuación las principales posturas mantenidas.

\section{Teoría de la no tributación de las ganancias ilícitas}

El primer tratado del que tenemos conocimiento es de Bacigalupo Saggese y en él defiende la tesis de que no existe obligación de tributar por las ganancias ilícitas y se apoya en los argumentos que a continuación se exponen y al mismo tiempo se intentan rebatir.

El primer argumento que esgrime es ético, considerando que «no se puede convertir al Estado en receptador o "partícipe" del delito»y, en caso contrario, habrá que explicar «qué diferencia existe entre su pretensión y la receptación o el blanqueo de capitales» ${ }^{37}$. Sorprenden estos escrúpulos éticos en quien, en páginas siguientes, defiende el decomiso como instrumento para combatir las ganancias del delito y nada dice de la posibilidad de considerarlo también como blanqueo de capitales. Efectivamente, el art. 127 CP impone el decomiso «de los bienes, medios o ins-

36 P. M. Herrera Molina, Fiscalidad..., op. cit., p. 27.

37 S. Bacigalupo Saggese, Ganancias ilícitas..., op. cit., pp. 22 y ss. 
trumentos con que se haya preparado o ejecutado, así como las ganancias provenientes del delito, cualesquiera que sean las transformaciones que hubieren podido experimentar» y añade que «se venderán, si son de lícito comercio, aplicándose su producto a cubrir las responsabilidades civiles del penado si la ley no previera otra cosa», que la prevé en el art. 374.4 CP para el tráfico de drogas: «no podrán ser aplicados a la satisfacción de las responsabilidades civiles derivadas del delito ni de las costas procesales, serán adjudicados íntegramente al Estado». Rechazar la tributación de las ganancias delictivas por motivos éticos debería dar lugar también al rechazo del decomiso, salvo que vaya dirigido a la destrucción de la cosa decomisada, lo que sólo sucede en el decomiso de efectos de ilícito comercio. Aparte de este argumento, como se ha expresado anteriormente, aplicar el blanqueo de capitales incluso al propio Estado daría lugar a que los bienes procedentes del delito o se restituyen a su legítimo titular, si es posible, o, si no lo es, tendrían que destruirse siempre, de lo contrario se cometería blanqueo de capitales.

El siguiente argumento que se aduce por la citada autora es que no se debe atender a la mera capacidad contributiva, sino a los actos que llevan a ella, así como el homicidio se debe valorar por los actos que llevan a él y no por el mero hecho de la muerte de una persona, que puede deberse, por ejemplo, a un paro cardiaco ${ }^{38}$. Sin embargo, en el supuesto de la generación de riqueza, el legislador, a fin de no dejar fuentes exentas de tributación, ha querido ser tan omnicomprensivo con la cláusula de cierre de la ganancia patrimonial no justificada antes referida, que precisamente si atendemos a los actos que dan lugar a la ganancia no parece que deban excluirse sino los expresamente previstos en el art. 7 LIRPF, muy escasos y singulares, y entre los que no se encuentra el hecho constitutivo de delito (ni de ilícito civil o administrativo).

$\mathrm{Al}$ recoger este argumento, la misma autora se refiere a que no cabe esgrimir el principio de igualdad para pretender la tributación de las ganancias ilícitas, porque si hay igualdad entre delincuentes y no delincuentes en relación con las leyes tributarias, también la habría «ante cualquier otra ley, lo que evidentemente no es así porque de la pena del delito se derivan determinadas inhabilitaciones que no afectan más que al condenado delincuente». Si este pasaje pretende decir que al delincuente se le castiga y al no delincuente no, no quiebra por ello la igualdad, pues no estamos ante casos iguales: en un supuesto se ha delinquido y en el otro

${ }^{38}$ Ibid., p. 24. 
no, y tratar de manera desigual lo que es desigual es una expresión más de la igualdad. Además, se le da al delincuente un trato más desfavorable, puesto que se le impone una pena. En el supuesto que nos ocupa no hay desigualdad, pues se tributa por la capacidad económica sin atender a la fuente, debiendo considerarse iguales los actos de igual capacidad económica. Aunque se entienda que la situación no es igual, desde luego no será el que ha obtenido su riqueza delinquiendo el que merezca el trato favorable de no tributar por ella. E incluso aunque se entendiera que debe quedar exenta de tributación la riqueza así obtenida, no cabe aplicar esa consecuencia jurídica sin una habilitación legislativa expresa, y la ley, como ya se ha dicho anteriormente, no menciona expresamente esta cuestión, pero más bien parece apuntar en sentido contrario a la no tributación del acto delictivo.

La autora menciona también como argumento para sostener su teoría el derecho a no declarar contra uno mismo ${ }^{39}$, que ya anteriormente se ha rebatido. Asimismo añade que cuando la LIRPF delimita el hecho imponible no pretende «gravar cualquier actividad económica, sino sólo aquella que tiene carácter empresarial, profesional o artístico y cuyo ejercicio presupone su licitud $»^{40}$. Sin embargo, la LIRPF, que no grava sólo este tipo de actividades, sino también otras muchas como el rendimiento del capital o las ganancias y pérdidas patrimoniales, nunca dice que la actividad deba ser lícita ni cabe presuponer, sino precisamente lo contrario, cuando contempla la tan citada cláusula de cierre de las ganancias patrimoniales no justificadas. Igualmente menciona ${ }^{41}$ que toda sociedad debe tener objeto lícito según el Código de Comercio; cierto, pero no es posible extraer de aquí la idea de que de ser ilícito el objeto estará la sociedad exenta de tributación. El ordenamiento impone muchas obligaciones a las sociedades, algunas más próximas que ésta a la materia fiscal, como el deber de publicar las cuentas anuales en el Registro Mercantil o de legalizar los libros contables, y, sin embargo, muchas sociedades incumplen estos deberes sin ninguna consecuencia tributaria, y si existiera alguna consecuencia en ningún caso podrá ser favorable al incumplidor.

Finalmente, la autora se refiere al posible concurso de delitos o de leyes, si bien, al considerar que no cabe tributación por ganancia ilícita, rechaza que exista ningún tipo de concurso ${ }^{42}$. Considera que las ganancias ilícitas

39 Ibid., p. 25.

${ }^{40}$ Ibid., p. 29.

${ }^{41}$ Ibid.

${ }^{42}$ Ibid., pp. 29 y ss. 
deben dar lugar al decomiso y no a la tributación, y que no cabe reforma legislativa en contrario, pues el Estado se estaría convirtiendo en partícipe del delito ${ }^{43}$. Este argumento, el decomiso, valdrá en el improbable supuesto de que se produzca en el mismo periodo impositivo en que tiene lugar la ganancia ilícita, porque así desaparece la ganancia patrimonial, pero si no tiene lugar en ese mismo periodo impositivo, no puede quedar la ganancia exenta de tributación por el hecho de que en algún momento pueda tener lugar ese decomiso.

La teoría de la no tributación de las ganancias ilícitas, al menos cuando constituyan ilícito penal, también se defiende por Ruiz de Erenchun Arteche, quien considera que no cabe tributación por tales ganancias, puesto que la tributación se basa en la capacidad económica y dicha capacidad no se manifiesta en quien obtiene ganancias delinquiendo, porque estas ganancias no se incorporan a su patrimonio, el verdadero titular de ese patrimonio será la víctima del delito ${ }^{44}$. No resulta convincente esta tesis, pues el delincuente habrá obtenido ese patrimonio al menos en apariencia y podrá guardarlo, reinvertirlo o gastarlo en lo que quiera, y todo ello será indicativo de capacidad económica. Quien le discuta la posesión deberá probar mejor derecho ante los tribunales. Si se entendiera la tributación de esta manera, cualquiera podría no tributar argumentando que es posible que algún día pueda considerarse que la fuente de sus ingresos fue delictiva (por ejemplo, que algún día se le pueda condenar porque la publicidad que hizo de sus productos fue engañosa, o porque con la venta de cierto producto cometió delito contra la propiedad intelectual o industrial, o que un nuevo producto financiero pueda algún día dar lugar a una condena por estafa). Incluso el obligado tributario podría manifestar rotundamente que no tiene ninguna deuda con Hacienda porque todos sus ingresos son de origen delictivo, acogiéndose a partir de ese momento a su derecho a no declarar contra sí mismo. No se le puede exigir que pruebe que sus ingresos han sido delictivos; será quien afirme que no lo son, y que, por tanto, debió tributar por ellos, quien deberá probar el absurdo de que no existió delito ${ }^{45}$. No es, pues, de recibo, desde esta fundamentación tampoco, la teoría de la no tributación de las ganancias delictivas.

${ }^{43}$ Ibid., p. 120.

44 E. Ruiz de ERenchun Arteche, «¿Hay que declarar...», op. cit., pp. 3 y ss.

${ }^{45}$ Esto equivaldría a probar que la ganancia es de origen lícito, pero esta carga de prueba no se le puede imponer a la Agencia Tributaria, pues el art. 39.1 LIRPF precisamente libera a la Administración de probar el origen de la ganancia, siendo suficiente con que quede probado que la ganancia ha existido. 
Sin embargo, el mismo autor rechaza que esta no tributación del acto ilícito se deba al derecho a no declarar contra uno mismo. Afirma que «la posible colisión del deber de tributar las ganancias ilícitas con el derecho a no declararse culpable parte ineludiblemente de la existencia del deber de tributar. Y ésa es precisamente la cuestión objeto de discusión. Sólo si se entiende que las rentas ilícitas están sujetas a tributación, puede abordarse la incidencia de este principio» ${ }^{46}$.

Finalmente insisto en que mi rechazo a la no tributación de las ganancias delictivas se sustenta, además, en un motivo práctico ya esbozado. Si las ganancias ilícitas no tributan, se podrá eludir la pena por fraude fiscal en numerosos supuestos de incrementos patrimoniales no justificados. Así, si se detecta que una empresa «A» dispone de un patrimonio que se supone formado mediante cobros en dinero negro a la empresa «B» por cuantía de la que derive una cuota tributaria superior a 120.000 euros en un mismo periodo impositivo, se le debe acusar y condenar por fraude fiscal. Sin embargo, si el empresario «A» se pone de acuerdo con el empresario «B» para que ambos simulen que «A» le ha hurtado a «B» esa cantidad, lograrán que «A» sea condenado por hurto, absuelto por fraude fiscal y el dinero regrese al patrimonio de «B» sin que Hacienda reciba su parte. A continuación «B» podrá volver a entregar clandestinamente el dinero a «A» detrayendo la parte que le corresponda, según lo pactado, por su concurso en esta maquinación. De acuerdo con la «doctrina Urralburu» este fraudulento modo de actuar beneficiará al empresario «A», liberándolo de la condena por fraude fiscal, pero al menos en vía administrativa sí se le podrá reclamar el pago del tributo, pues recuérdese que esta doctrina no niega el deber de tributar, sólo excluye la condena por los dos delitos basándose en el supuesto concurso de leyes entre ambos. Pero una teoría negadora del deber de tributar por las ganancias delictivas no sólo daría lugar a que el empresario «A» quedara liberado de condena por fraude fiscal desde el momento en que se le condenase por el supuesto delito de hurto, sino que además lo dejaría exento del deber de tributar y ni aun en vía administrativa se podría reclamar la cuota tributaria defraudada.

${ }^{46}$ E. Ruiz de Erenchun Arteche, «Caso Urralburu», op. cit., p. 4. 


\section{Teoría favorable a la tributación de las ganancias ilícitas}

Luzón Cánovas considera que la tributación de las ganancias ilícitas plantea problemas únicamente cuando ese ilícito del que provienen las ganancias es constitutivo de delito, porque en otro caso entrará en juego la cláusula de la ganancia patrimonial no justificada sin que quepa hablar de controversia alguna en relación con la obligación de declarar ${ }^{47}$.

Señala como argumentos a favor de la tributación de la ganancia de origen delictivo que no existe precepto legal que la excluya, que se tributa por el beneficio (siendo irrelevante la operación que lo genera) y que si no se introduce la tributación de tales rentas se podrían reinvertir estas ganancias sucesivamente sin tributación ${ }^{48}$. Como argumentos en contra señala que, desde el punto de vista ético, el Estado estaría beneficiándose de ganancias obtenidas ilícitamente y que desde posiciones civilistas se destaca que los contratos con causa ilícita son nulos, que lo obtenido ilícitamente no es propiedad de quien lo obtiene o que las sociedades deben tener objeto social lícito ${ }^{49}$. También destaca que reiteradamente se han invocado diversos obstáculos constitucionales, como el derecho a no declarar contra uno mismo y no confesarse culpable, la no exigibilidad de otra conducta, el acto posterior impune o el principio ne bis in idem ${ }^{50}$.

La conclusión a la que este autor llega es que «no existe norma constitucional alguna en virtud de la cual el delincuente pueda invocar válidamente un derecho a no declarar las ganancias ilícitamente obtenidas [...] Por el contrario, el principio de igualdad ante el impuesto impide conceder un tratamiento fiscal más favorable a quien viola el derecho que a quien lo respeta, lo que determina, junto a la existencia de capacidad económica en quien comete el delito, que pueda considerarse gravable esta concreta manifestación de riqueza. Corresponderá en definitiva al legislador determinar si la posesión de una renta ilícita debe ser configurada como hecho imponible o no, en una decisión de política tributaria perfectamente legítima por la que se aplicarían estos fondos al cumplimiento de los fines propios de un Estado social» ${ }^{51}$. De aquí parece entenderse que considera que puede imponerse la tributación por las ganancias obtenidas

\footnotetext{
47 A. LuZÓN CÁNOVAS, «Aspectos constitucionales...», op. cit., p. 3.

${ }^{48}$ Ibid., p. 1.

${ }^{49}$ Ibid., p. 2.

50 Ibid., pp. 2 y ss.

${ }^{51}$ Ibid., p. 17.
} 
delinquiendo, pero que lo cierto es que el legislador no lo ha hecho todavía. Aunque a renglón seguido entiende que la sentencia del caso Urralburu, como se señaló anteriormente, «no representa un avance respecto a la más correcta que puso fin al caso Roldán, ya que dispone un inexistente concurso de normas». Si piensa que es más correcta la sentencia del caso Roldán, parece que en realidad se muestra favorable a la tributación de las ganancias ilícitas y a que, en caso de no tributarse por ellas, pueda imponerse condena por fraude fiscal, aunque considere que el legislador deba determinarlo expresamente para evitar la polémica doctrinal existente sobre el tema. Parecer que suscribo plenamente.

\section{Teoría intermedia de Herrera Molina}

También ha tratado el tema en profundidad Herrera Molina, quien parte del art. 13 LGT cuyo contenido es el siguiente: «Las obligaciones tributarias se exigirán con arreglo a la naturaleza jurídica del hecho, acto o negocio realizado, cualquiera que sea la forma o denominación que los interesados le hubieran dado, y prescindiendo de los defectos que pudieran afectar a su validez». Sobre esta base infiere que la legislación tributaria sí establece una norma aplicable a los supuestos de ilicitud del hecho imponible que es ésta, es decir, la irrelevancia de la ilicitud, por lo que la consecuencia jurídica será el sometimiento a gravamen del mismo modo que si no existiera ilicitud ${ }^{52}$. No obstante, a continuación, y partiendo de los arts. 1.305 y 1.306 del Código Civil, hace una importante distinción.

Recordemos que estos artículos prescriben lo siguiente:

«Art. 1.305 CC. Cuando la nulidad provenga de ser ilícita la causa u objeto del contrato, si el hecho constituye un delito o falta común a ambos contratantes, carecerán de toda acción entre sí, y se procederá contra ellos, dándose, además, a las cosas o precio que hubiesen sido materia del contrato, la aplicación prevenida en el Código Penal respecto a los efectos o instrumentos del delito o falta.

Esta disposición es aplicable al caso en que sólo hubiere delito o falta de parte de uno de los contratantes; pero el no culpado podrá reclamar lo que hubiese dado, y no estará obligado a cumplir lo que hubiera prometido».

52 P. M. Herrera Molina, Fiscalidad..., op. cit., p. 39 
«Art. 1.306 CC. Si el hecho en que consiste la causa torpe no constituyere delito ni falta, se observarán las reglas siguientes:

1. ${ }^{\text {a }} \quad$ Cuando la culpa esté de parte de ambos contratantes, ninguno de ellos podrá repetir lo que hubiera dado a virtud del contrato, ni reclamar el cumplimiento de lo que el otro hubiese ofrecido.

2. $\quad$ Cuando esté de parte de un solo contratante, no podrá éste repetir lo que hubiese dado a virtud del contrato, ni pedir el cumplimiento de lo que se le hubiera ofrecido. El otro, que fuera extraño a la causa torpe, podrá reclamar lo que hubiera dado, sin obligación de cumplir lo que hubiera ofrecido».

Infiérese de ambos artículos que los contratos con causa ilícita, sea o no constitutiva de delito, pueden distinguirse en dos tipos según la ilicitud sea aplicable a ambas partes o a una sola. En el primer caso no habrá acción entre ellas, ninguna parte podrá reclamar lo que haya entregado ni lo que la otra haya ofrecido, pero en el segundo caso, cuando sólo sea imputable a una de las partes, la otra sí podrá reclamar tanto lo que haya entregado como lo que la otra haya ofrecido. Esto será así sea o no el hecho constitutivo de delito. Sobre esta base el citado autor entiende que debe distinguirse la posible tributación de actos delictivos según el delito sea imputable a una sola de las partes, como sucede en el hurto, o a las dos, como sucede en el cohecho. En el primer caso no cabe tributación, pues la consecuencia jurídica aplicable será la restitución de la cosa a quien haya sido privado delictivamente de ella. En el segundo supuesto sí cabe la tributación, puesto que ninguna de las partes podrá reclamar a la otra ${ }^{53}$. Excluir la tributación en caso de restitución tiene apoyo jurisprudencial; así, las SSTS núms. 2154/199954

53 Ibid., pp. 31, 35 y ss.

${ }^{54}$ La STS (Sala Tercera, Sección 2. ${ }^{a}$ ) núm. 2154/1999, de 27 de marzo, distingue «entre el modo de proceder de los impuesto indirectos y de los directos, cuando los actos y contratos no llegan a buen fin. En el Impuesto sobre Transmisiones Patrimoniales y Actos Jurídicos Documentados, verdadero paradigma en esta cuestión de los impuestos indirectos, cuando se declare o reconozca judicial o administrativamente, por resolución firme, haber tenido lugar la rescisión o resolución de un acto o contrato, el contribuyente tendrá derecho a la devolución de lo que satisfizo por cuotas del Tesoro, de no haberse hecho el pago mediante efectos timbrados, siempre que no le hubiere producido efectos lucrativos, y que se reclame la devolución en el plazo de cinco años. Igual régimen, en lo esencial, se aplicaba en el extinguido Impuesto General sobre el Tráfico de las Empresas y en el Impuesto sobre el Valor Añadido vía deducción o devolución. Por el contrario, en los impuestos directos, y, concretamente, en el Impuesto sobre Sociedades, que no grava los actos y contratos, pues su hecho imponible tiene un substrato económico, sino la obtención de renta, las operaciones económicas se imputan temporalmente, como hemos dicho, siguiendo la corriente real de bienes y servicios (ingresos y gastos), prescindiendo del momento de pago (corriente financiera), si bien las 
y $3199 / 2000^{55}$, tratando la ineficacia jurídica del acto gravado, consideran que si se trata de un impuesto indirecto procede la devolución de lo pagado, mientras que si se trata de un impuesto directo sólo sería posible computar una pérdida en el periodo impositivo en que ésta se produzca. La misma solución se ha dado al problema en Francia, Alemania y Estados Unidos, pero no en Italia ${ }^{56}$.

En realidad, la solución es parecida, se trate de impuesto directo o indirecto, sólo que en el primer caso la devolución se lleva a cabo por la vía de la deducción por pérdida. Sin embargo, el hecho de que esta jurisprudencia conceda relevancia a la ineficacia del acto gravado puede llevarnos a considerar relevante que este acto sea delictivo, pero no hay por qué inferir de aquí un trato diferente según el delito sea imputable a una parte o a las dos. En definitiva, no comparto la distinción que realiza este autor, pues si en caso de delito imputable a una sola parte el motivo por el que considera que el acto no queda sujeto a tributación es por no haber existido incremento de patrimonio, lo mismo debiera pensar del supuesto en que el delito es imputable a ambas partes, no hay incremento patrimonial tampoco por quedar el acto sujeto a comiso. Además, mientras no se proceda a la restitución habrá habido un incremento patrimonial, pues no sólo la pro-

posibles situaciones de insolvencia, es decir, el incumplimiento de las obligaciones de pago que se produzcan, son desde la perspectiva de la economía de la empresa y de la contabilidad hechos posteriores que implican un resultado inverso, es decir, se consideran partidas negativas, antes incluso de que la operación se revoque, rescinda o desemboque en la falencia definitiva, sin que haya retroacción, ni compensación de resultados, sino que éstos son contemplados in suo tempore, de modo separado, aunque en sentido inverso».

55 STS (Sala Tercera, Sección 2. ${ }^{a}$ ) núm. 3199/2000, de 14 de abril: «En los impuestos cuyo hecho imponible, como dice el art. 25.2 de la Ley General Tributaria, vigente en los años a que se refieren los presentes autos, consista en un acto o negocio jurídico, si se ha acordado bajo condición resolutoria, es incuestionable que el cumplimiento de la misma llevará consigo su resolución, que por su propia naturaleza se retrotraerá al momento de su celebración y llevará consigo la devolución del impuesto correspondiente, salvo que hubiera existido efecto lucrativo, pero estas normas no son aplicables del mismo modo en los impuestos cuyo hecho imponible se delimita atendiendo a conceptos económicos, como ocurre con el Impuesto sobre Sociedades, porque para éste el acto o contrato inicial es una operación económica que ha generado un resultado, supongamos que positivo, que se contabiliza como beneficio, y tributa por Impuesto sobre Sociedades, pero si años después, se resuelve el contrato por cumplimiento de una condición resolutoria o por anulación, rescisión o resolución judicial o administrativa, este acto resolutorio es una operación económica distinta, que se contabiliza en el ejercicio en que se ha producido, y que probablemente habrá generado una pérdida, de ahí que en el Impuesto sobre Sociedades no haya que retrotraer los efectos de la anulación, resolución, etc., de los actos o contratos al momento en que se pactaron, sino que se reflejan, como una operación distinta, en el ejercicio, insistimos, en que se producen».

${ }_{56}$ P. M. Herrera Molina, Fiscalidad..., op. cit., p. 67. 
piedad, también la mera posesión forma parte del patrimonio y se puede obtener rendimiento económico de ella. Ahora bien, sí entiendo correcta la argumentación indicada para el supuesto en que, tratándose de un tributo periódico, antes de concluir el periodo impositivo ya haya el autor sufrido la pérdida de la cosa objeto del delito como consecuencia de la restitución a su legítimo propietario, pues en el momento de la declaración de impuestos no existe ya el incremento patrimonial. Si llegado el momento de la declaración se mantiene la cosa en poder del contribuyente, deberá tributar por ella, sin perjuicio de que proceda posteriormente la deducción por pérdida a que se refieren las citadas sentencias. Si el delito es imputable a las dos partes también se debe tributar por la ganancia, otra cuestión será que haya derecho a devolución en caso de decomiso.

El Estado no puede excluir este supuesto de tributación, pues dejaría en manos de particulares el deber de tributar, aun cuando el delito sea perseguible de oficio, pues la acción civil sí es disponible. Si el perjudicado renuncia a la acción civil, quedaría quien ha cometido el hurto en poder de la cosa sin tributar por ella. Esta insatisfactoria consecuencia no puede evitarse obligando a tributar en caso de renuncia a la acción civil, porque también puede existir reserva de acciones para ejercitarlas ante el orden civil, y este ejercicio tendrá lugar cuando el perjudicado lo estime conveniente (si es que finalmente lo ejerce). Pero tampoco nos parece razonable imponer el deber de declarar tributariamente lo hurtado sólo cuando haya prescrito la acción para reclamar el objeto del hurto, que será el supuesto en el que ya de ningún modo podrá éste reclamarse por el legítimo propietario. También hay delitos, algunos muy lucrativos como los societarios, que no son, en principio, perseguibles de oficio (art. 296 CP). En definitiva, se pretende con todo esto poner de relieve que aplicando la teoría defendida por este autor se estaría dejando la obligación de tributar en manos de particulares que puedan simular un delito, denunciarlo o no, renunciar o reservarse la acción civil, y, en este último caso, ejercitarla o no.

Si el ilícito fuera administrativo, «en muchos casos la reacción consistirá tan sólo en la imposición de una multa, que no constituirá gasto deducible ni podrá deducirse como gasto [art. 14.1.c) LIS] [actual 15.c)]. En ocasiones, la ley prevé también el comiso como sanción accesoria» ${ }^{57}$. Parece extraerse de aquí, aunque el autor no llega a dejarlo del todo claro, que entiende tributable la ganancia procedente del ilícito administrativo, salvo comiso.

${ }^{57}$ Ibid., pp. 70 y ss. 
Cuando se trate de ilícito penal, de acuerdo con lo antes expuesto, el citado autor distingue según exista o no obligación de restituir. El segundo supuesto se dará cuando el delito sea imputable a ambas partes y la consecuencia jurídica, de acuerdo con el art. 1.305 CC, será «la aplicación prevenida en el Código Penal respecto a los efectos o instrumentos del delito o falta», es decir, el decomiso ${ }^{58}$. El primer supuesto se dará cuando el delito sea imputable a una parte y la obligación de restituir, entiende este autor, excluye la obligación de tributar. Esta conclusión la basa en que la mera detentación de bienes como consecuencia de un delito no puede considerarse renta gravable, porque no es ganancia patrimonial. Podría no haber sido éste el criterio del legislador y haber establecido el gravamen sobre la base del control real de los bienes como sucede en Alemania y Estado Unidos (incluso en España se ha seguido este criterio al establecer las presunciones de renta, que orbitan en torno al control real de los bienes y no en torno al incremento patrimonial que puedan generar, porque el Derecho tributario no está subordinado al Derecho civil), pero no es esto lo que ha sucedido en relación con las ganancias ilícitas, donde no se establece tributación por el control real de tales ganancias ${ }^{59}$. Entiendo correcta esta argumentación, pero no está expresamente prevista la exclusión de tributación de esta «detentación» por la legislación tributaria, e interpretar la norma jurídica de este modo nos podría llevar al fraude de simular delito para evitar la tributación, como anteriormente se dijo. Como ésta no ha podido ser de ningún modo la voluntad del legislador, considero que la interpretación referida no es correcta si atendemos al espíritu y finalidad de la norma según el art. 3.1 CC. Por no tratarse de norma penal no hay razón para que prevalezca la interpretación literal.

El mismo autor también realiza una interesante clasificación de rentas delictivas atendiendo a las categorías de tributación. Así, considera que deben tributar por IRPF en la modalidad de rendimientos del trabajo (art. $17 \mathrm{LIRPF}$ ) las ganancias que obtengan los miembros de una organización criminal que reciban una retribución de dicha organización. Por la modalidad de rendimientos del capital tributarán los que concedan préstamo con interés para actividades criminales (rendimiento del capital mobiliario, arts. 21 y 25.2 LIRPF) o arrienden sus bienes para los mismos fines (rendimiento del capital inmobiliario, arts. 21 y 22 LIRPF). Por la moda-

${ }^{58} \mathrm{Ibid}$., p. 84. En p. 96 entiende que no cabe decomiso de las ganancias lícitas obtenidas con fondos delictivos, es decir, en caso de reinversión lícita de la ganancia procedente de un delito.

${ }^{59}$ Ibid., pp. 82 y ss. 
lidad de actividades económicas tributará el que lleve a cabo, como dice el art 27 LIRPF, «la ordenación por cuenta propia de medios de producción y de recursos humanos o de uno de ambos, con la finalidad de intervenir en la producción o distribución de bienes o servicios», como sucede con los que se dediquen al tráfico de drogas, armas o personas; los que se dediquen a la comisión de delitos contra la propiedad intelectual o industrial, o los que cometan intrusismo. Otros supuestos no clasificables en las categorías anteriores, como el cohecho, pueden tributar en la modalidad de ganancias y pérdidas patrimoniales (art. 33 LIRPF). En caso de que el delincuente no sea residente en España se tributará del mismo modo, pero aplicando el Impuesto sobre la Renta de los no Residentes ${ }^{60}$.

La obra comentada por su fecha de publicación no se plantea la tributación aplicando el Impuesto sobre Sociedades, pero entendemos que desde la introducción en el Código Penal de la responsabilidad penal de las personas jurídicas mediante la LO 5/2010, las ganancias obtenidas delictivamente por una persona jurídica deberán someterse a este tributo. Cuestión diferente será que se cree la persona jurídica con intención de delinquir, en cuyo caso no cabe exigir responsabilidad penal a una persona jurídica existente sólo en apariencia, sino que la renta deberá aplicarse directamente a la persona física para evitar que resulte ésta privilegiada por la aplicación de un impuesto menos gravoso, como es el de sociedades, frente al tipo de gravamen aplicable a las rentas altas en el IRPF.

Al tiempo que se habla de la tributación de las ganancias delictivas debe hablarse de la deducibilidad de los gastos sufridos en esas actividades delictivas - gastos que fueron necesarios para obtener tales ganancias-, puesto que en el Impuesto sobre Sociedades la base imponible está formada por el beneficio de la sociedad, es decir, los ingresos menos los gastos. Por curiosa que pueda parecer esta deducibilidad, en septiembre de 2000 la OCDE consideraba que hasta fechas recientes en muchos países miembros de dicha organización se consideraba un gasto deducible el soborno de funcionarios públicos extranjeros si era necesario para llevar a cabo operaciones comerciales en ese país ${ }^{61}$. En Alemania se prohibió expresamente esta deducibilidad en 199962. En España no existía regulación específica sobre

${ }^{60}$ Ibid., pp. 91 y ss.

${ }^{61}$ Informe de la OCDE, «The fight against bribery and corruption»: «Until recently, the bribery of foreign public officials has been accepted as a normal cost of doing business by many OECD countries», septiembre de 2000, http://www.oecd.org/governance/ ethics/1918235.pdf.

62 P. M. Herrera Molina, Fiscalidad..., op. cit., p. 124. 
el tema, pero la entrada en vigor el 1 de enero de 2015 de la Ley 27/2014, de 27 de noviembre, del Impuesto sobre Sociedades, ha supuesto la prohibición de la deducibilidad de tales gastos de acuerdo con lo establecido en el apartado $f$ ) de su art. $15^{63}$. No obstante, de esta prohibición en absoluto cabe extraer que las ganancias delictivas no deban tributar, pues tampoco son deducibles los donativos y liberalidades realizados [art. 15.e) LIS], y, sin embargo, los recibidos sí son tributables, y el propio Plan General de Contabilidad ${ }^{64}$ prevé que en el subgrupo 74 , por tanto, dentro del grupo de cuentas de ingresos, deben anotarse las «subvenciones, donaciones y legados». La letra $g$ ) del mismo art. 15 también excluye los gastos realizados en paraísos fiscales, salvo que se pruebe que han sido reales, mientras que no existe ninguna salvedad respecto de los ingresos obtenidos en tales paraísos. En fin, se quiere decir que no existe correlación rigurosa entre los ingresos y los gastos deducibles, por tanto, la actual prohibición de deducción de los gastos realizados en actividades delictivas no supone exclusión de la tributación de las ganancias obtenidas en tales actividades.

\section{Teoría intermedia de Galarza}

Galarza plantea las dos teorías sobre la tributación de las ganancias ilícitas considerando que a favor de la tributación se suele esgrimir el argumento de la igualdad. Sería injusto que quien se dedica a un negocio lícito tenga que tributar y enfrentarse a la competencia desleal de quien realizando un negocio similar, por ser ilícito, quede eximido de este deber. «El rechazo palmario a tal desigualdad (contraria al principio de igualdad), sumada - hay que reconocerlo- a la creciente necesidad de obtener recursos para el Estado, ha llevado a que numerosas administraciones fiscales de Estados europeos hayan visto oportuno exigir el pago del tributo ante la realización de un acto ilícito. Dichas pretensiones fueron recurridas por los "eventuales sujetos pasivos" ante los Tribunales de Justicia de sus respectivos países e, incluso, ante los Tribunales de la Unión Europea. Sin embargo, ni los respectivos organismos judiciales nacionales ni los comunitarios han podido, hasta el momento, concretar una opinión unívoca al respecto, ya que si bien es cierto que en algunas ocasiones han rechazado

${ }^{63}$ No tendrán la consideración de gastos fiscalmente deducibles: «los gastos de actuaciones contrarias al ordenamiento jurídico».

${ }_{64}$ Real Decreto 15/2007, de 16 de noviembre, por el que se aprueba el Plan General de Contabilidad. 
la tributación de los actos ilícitos, en otras, recurriendo a argumentos similares, la han aceptado» ${ }^{65}$.

Los argumentos en contra suelen orbitar en torno a «consideraciones moralistas amparadas en la eventual conformación de un Estado inmoral o cómplice de la comisión de ilícito y que se aprovecha de lo producido en el mismo», si bien puntualiza que «las leyes tributarias no se conciben para reformar o vigilar la conducta ética o moral de los ciudadanos, sino para procurar recursos al erario público» ${ }^{66}$.

La solución propuesta por este autor consiste en valorar si la ilicitud del acto invalida la configuración del hecho imponible. A modo de ejemplo se refiere a que si el hecho imponible es la venta de un bien y es inválido el contrato de compra-venta, no tiene lugar el hecho imponible y, por tanto, no hay obligación de tributar, pero si el hecho imponible es la transmisión del bien como realidad fáctica, la ilicitud será independiente del hecho imponible y, por tanto, sí existirá obligación de tributar ${ }^{67}$. De acuerdo con lo dicho concluye que en casos de ilícito penal, como no se producirá ningún efecto jurídico, no habrá obligación de tributar, porque además en estos supuestos será de aplicación el decomiso, que excluirá la capacidad económica vaciando el hecho imponible ${ }^{68}$.

Rebatiendo esta postura, insisto en que se habrá producido un efecto importante, la adquisición de la posesión y todo lo que ello conlleva; por tanto, de ninguna manera cabe decir que no se produce ningún efecto jurídico, y en relación con el decomiso, como se ha señalado anteriormente, mientras éste no se produzca no cabe argumentarlo para excluir la aplicación de las leyes tributarias.

\section{CONCLUSIONES}

Los principales argumentos a favor de la tributación de las ganancias ilícitas son la igualdad frente a la ganancia lícita, la inexistencia de norma que excluya esta tributación, la obligación de tributar por el incremento patrimonial no justificado, la existencia de un acto que supone capacidad económica como habitual presupuesto de la tributación y la necesidad de

${ }^{65}$ C. J. Galarza, «Algunas cuestiones sobre la tributación de los actos ilícitos», Laleydigital360, núm. 502 (2012), p. 1.

${ }^{66}$ Ibid., p. 3.

${ }^{67}$ Ibid., p. 2.

${ }^{68}$ Ibid., p. 4. 
introducir la tributación en la cadena de reinversiones que puede existir a continuación. Los principales argumentos en contra son los motivos éticos que impiden al Estado participar en el beneficio obtenido ilícitamente, motivos iusprivatísticos que orbitan en torno a la ineficacia del acto ilícito, la inexistencia de un acto indicativo de capacidad económica dada la obligación de restituir al perjudicado o, en su caso, el decomiso, y los constitucionales derechos a no declarar contra uno mismo y a no confesarse culpable, así como un posible quebranto del principio ne bis in idem.

Las ganancias ilícitas - también las que nazcan de un ilícito penaldeben tributarse, principalmente porque ninguna norma jurídica apunta en el sentido de su no tributación y sí, en cambio, en el sentido de que deben someterse a gravamen (art. 39 LIRPF). Asimismo, los argumentos contrarios a esta tesis desde el punto de vista teórico no son convincentes y desde el punto de vista práctico podrían dar lugar al fraude masivo amparándose en el supuesto origen delictivo de la ganancia.

La jurisprudencia penal española pocas veces se ha pronunciado sobre el tema y siempre ha sostenido que debe tributarse por la ganancia ilícita, pero desde la sentencia del caso Urralburu, y so pretexto de un concurso de leyes que no justifica y que es en realidad, y a todas luces, un concurso material de delitos, se excluye de pena el fraude fiscal si se castiga por el delito fuente de la ganancia. El escaso arraigo en España de la idea de la tributación de las ganancias ilícitas se pone de relieve por las contadas ocasiones en que la jurisprudencia se ha pronunciado sobre el tema, casi siempre en casos de resonancia pública, y en los que probablemente, por diversos motivos, se ha querido dar al acusado un castigo mayor acudiendo a un delito que, aunque existente, es muchas veces olvidado.

En Italia, Alemania, Francia y Estados Unidos está expresamente prevista la tributación de las ganancias ilícitas. Sería deseable que en España también se previera expresamente, máxime considerando la polémica doctrinal existente sobre el tema. 